Discussion Paper No. 06-025

\title{
Wage and Productivity Effect of Continuing Training in Germany: A Sectoral Analysis
}

Anja Kuckulenz

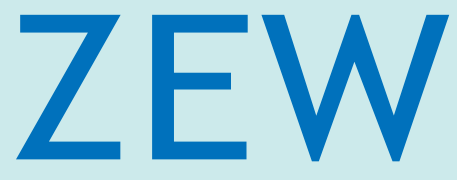

Zentrum für Europäische Wirtschaftsforschung $\mathrm{GmbH}$

Centre for European

Economic Research 
Discussion Paper No. 06-025

\title{
Wage and Productivity Effect of Continuing Training in Germany: A Sectoral Analysis
}

\author{
Anja Kuckulenz
}

Download this ZEW Discussion Paper from our ftp server:

ftp://ftp.zew.de/pub/zew-docs/dp/dp06025.pdf

Die Discussion Papers dienen einer möglichst schnellen Verbreitung von neueren Forschungsarbeiten des ZEW. Die Beiträge liegen in alleiniger Verantwortung der Autoren und stellen nicht notwendigerweise die Meinung des ZEW dar.

Discussion Papers are intended to make results of ZEW research promptly available to other economists in order to encourage discussion and suggestions for revisions. The authors are solely responsible for the contents which do not necessarily represent the opinion of the ZEW. 


\section{Non-technical summary}

In this paper, wage and productivity effects of continuing training are estimated and compared in order to analyse who gains from workers' training. Investments in continuing training are undertaken in order to raise the level of qualification in a firm and to secure its economic performance. Whether these investments in training are profitable to the individual, the firm and society as a whole is still unclear although the question is of considerable importance. Most studies on the productivity impact of training take wages as a proxy for productivity. The focus of this paper is on comparing wage and productivity effects in order to study how the training rent is shared between employers and employees. The use of system GMM techniques allows me to account for endogeneity and time invariant unobserved factors.

In more detail, wage and productivity effects are estimated and compared using panel data on the industry level in order to analyse the extent to which employer and employees gain from continuing training. This empirical analysis at the sectoral level suggests that the rent sharing aspect of training is important for employer and employees in Germany. Results show that both employer and employees profit from the investment in human capital. The estimated productivity effects of training are higher, on average, than the wage effects.

Since the estimated effect of continuing training on productivity exceeds the effects estimated by comparable studies using firm level data, my results hint to the existence of external effects of training on a sector level, that is, spillovers from training between firms in the same sector.

The results of former work suggest that skill group heterogeneity of the training impact on wages should be considered. In order to shed light on this issue and to analyse whether the impacts of participating in training on wages and on productivity differ for low and highly skilled workers, I differentiate between these two groups. This extension enables me to analyse whether there are spillovers between the two skill groups. I test whether training participation of high skilled has an influence on wages of low skilled or the other way around. High skilled workers seem to capture a larger share of the rent than low skilled workers. This result is consistent with former work. In addition, I do not find positive external effects of firm-provided training between skill groups. 


\title{
Wage and Productivity Effect of Continuing Training in Germany: A Sectoral Analysis ${ }^{1}$
}

\author{
Anja Kuckulenz \\ ZEW Mannheim
}

April 12, 2006

${ }^{1}$ I thank Nicole Gürtzgen, Michael Maier, Friedhelm Pfeiffer and Alexandra Spitz for helpful comments and Iliyan Stankov for his excellent research assistance. This work was supported by the Deutsche Forschungsgemeinschaft (DFG) through the research group Heterogeneous Labour. Neither the Bundesinstitut für berufliche Bildung (BIBB), the Institut für Arbeitsmarkt- und Berufsforschung (IAB) nor the Zentralarchiv (ZA) take any responsibility for the analysis or the interpretation of the data presented here. 


\begin{abstract}
Wage and productivity effects of training are compared to study how the training rent is shared between employers and employees. With panel data from 1996-2002, I analyse the impact of continuing training on wages and productivity in a Cobb-Douglas production framework. Using system GMM techniques allows me to account for endogeneity and time invariant unobserved factors. Results suggest that the training rent is shared between employer and employee due to a positive effect of continuing training on both wages and productivity. The effect on productivity is about three times higher than the one on wages. High skilled workers capture a larger share of the rent than low skilled workers.
\end{abstract}

Keywords: continuing vocational training, system GMM estimation, wage effect, productivity effect, external effect

JEL-Codes: J24, J31, C21, C23 


\section{Introduction}

Investments in continuing training are undertaken in order to raise the level of qualification in a firm and to secure its economic performance. There are also arguments for subsidising continuing training which relate to the society's perceived social and economic benefits from such investments which ought to boost productivity and growth. The main arguments are positive external effects of continuing training which induce welfare gains and technological progress. Whether these investments in training are profitable to the individual, the firm and society as a whole is still of considerable importance. While most studies for Germany take wages as a proxy for productivity and find a positive effect of training on productivity, the impact is ambiguous in the few studies using direct measures of productivity. Also, in recent work on training effects on wages where panel data and advanced econometric methods are used, the positive effect of training vanishes (for Germany, see Jürges and Schneider, 2005; Kuckulenz and Maier, 2006).

Human capital externalities play a prominent role in recent growth theory (Barro, 2001). In empirical work with individual data some recent studies try to estimate the externality caused by education (for example, Ciccone and Peri, 2002; Acemoglu and Angrist, 2000). While investment in continuing training is alleged to give rise to spillover benefits, empirical support for the existence of such positive external effects is scarce and weak, however. Recently, Martins (2005) reports large firm-level social returns from on-thejob training accruing from spillovers that benefit less educated workers. No statistically significant effect of education on earnings is found by Isaacsson (2005). In addition, knowledge about how the rent resulting from investment in training is shared between employer and employee is scarce (see, for example, Booth, Francesconi and Zoega, 2003; Dearden, Reed, van Reenen, 2005).

In this paper, both wage and productivity effects are estimated and compared with panel data on the industry level in order to analyse who gains from investment in training. To the best of my knowledge, it is shown for the first time with German data that the rent sharing aspect between employer and employees is important for company provided training. Results show that employer and employees both profit from the investment in human capital. The estimated productivity effects of training are higher than the wage effect. In addition, the results hint to the existence of positive external effects from training on productivity. Comparing the estimated coefficients to the results of comparable studies using firm data, I find evidence for knowledge spillovers between firms in the same sector. Previous work has shown that the training impact on wages differs for low and high skilled workers (e.g., Kuckulenz and Zwick, 2003). In order to shed light on this issue and analyse whether the impacts of participating in training on wages and on productivity differ between low and high skilled workers, I differentiate between these two groups. This extension enables me to analyse whether there are spillovers between the 
two skill groups.

I will proceed as follows: Section 2 discusses the results from previous literature. Section 3 explains how the data set is set together and Section 4 presents some descriptive statistics. Section 5 describes the estimation strategy. Section 6 discusses the results for the basic model and Section 7 for the extension where I differentiate between low and high skilled workers. Section 8 summarises and concludes.

\section{Background Discussion}

Wages, profits and rent-sharing have been a topic for macroeconomists as well as for labour economists (for example, Blanchflower, Oswald and Sanfey, 1996; MacLeod and Malcomson, 1993). Empirical evidence has shown that when firms become more prosperous, workers eventually receive some of the gains (Hildreth and Oswald, 1997; Arai, 2003; Estevao and Tevlin, 2003). The central prediction of noncompetitive theories is also that rents are divided between firms and employees (e.g. Brown, Falk and Fehr, 2004). In a randomised field experiment, Fehr and Götte (2004) show that workers are willing to supply more labour when their wage increases. This is not in line with standard life cycle models but can be explained by preference spillovers across periods and reciprocate behaviour. Only few theoretical and empirical work has focused on the relationship between training investments and rent sharing. Booth and Zoega (1999) show that turnover in a company comprises a negative externality. By causing the firms' discount rate to exceed the social discount rate, high turnover thus leads to an underinvestment in training. Burdett and Smith (2002) find within a matching model that rent sharing diminishes the worker's incentive to acquire skills but the subsequent improved matching prospects may offset the initial disincentive to invest. McLaughlin (1994) and Piekkola and Kauhanen (2003) show that highly educated workers are the main target of rent sharing. Thus, it is important to take heterogeneity of the workforce into account.

If there is a positive productivity effect of training, there is a rent to share and either wages should increase, or firms value added per worker, or both. How the rent is shared between employer and employee may depend on several aspects. First, the productivity increase from training can be divergent for different training forms and can differ for heterogenous participants. Thus, it can influence how the training rent is shared. Second, the rent sharing obviously depends on who pays for training. Third, whether an employee profits from training or not may also be influenced by the respective bargaining power of the worker and the firm. Former evidence suggests that it is likely that workers have less bargaining power (ceteris paribus) if they are less qualified, if they work for a large firm, when they just entered a firm or when they are on a fixed term contract. Firms are likely to have less bargaining power (ceteris paribus) when few workers with comparable human capital are available, when workers are not restricted in their mobility, or when demand for workers is much higher than supply in a labour market (Kuckulenz and 
Zwick, 2003).

Former empirical evidence on productivity effects of training is rather mixed (compare, for example, Blundell, Dearden, Meghir and Sianesi, 1999; Dearden, Reed, and van Reenen, 2000; Zwick, 2005). An important part of this heterogeneity might be due to the varying methodological strategies. Crosssection estimations might be biased because some explanatory variables, like capital and labour, are endogenous (Griliches and Mairesse, 1998 or Boon and Van der Eijken, 1997) and unobserved time invariant factors, such as technological change in economic sectors, which can be correlated with both, training and productivity, cannot be accounted for. Unless I control for these fixed effects, I may overestimate the importance of training for productivity. I use panel estimation methods, which eliminate unobserved time invariant heterogeneity. Some studies have pointed to the endogeneity of training: the decision to invest in training is likely to depend on firm's performance. Empirical studies show that less productive firms tend to invest more in training (see Dearden, Reed, and van Reenen, 2000; Zwick, 2002). It is likely that firms may reallocate idle labour to training activities when they face a downturn in demand in their industry. Therefore, it is crucial to control for endogeneity of continuing training because otherwise the true productivity contributions of training will be understated.

Recently, comparisons of wage and productivity effects of training were made in empirical papers (Bartel, 1995; Rennison and Turcotte, 2004; Lopez-Acevedo, 2003; Dearden, Reed and Van Reenen, 2000). In these studies, the effect of training on both wages and productivity is computed, which allows to estimate the shares accrued to the firm and to the worker, respectively. Bartel (1995) uses performance scores as an indicator for productivity and finds a positive impact of training on wage growth as well as on productivity. Using Spanish firm-level data, Alba-Ramirez (1994) finds a positive correlation between training investments and productivity as well as with wages. Dearden, Reed and Van Reenen (2000) estimate a positive effect of training on productivity with a British panel of aggregated data (on industry level) and find that the impact is underestimated when taking wages as a proxy. In studies with Canadian and Mexican linked employer employee data, this result is confirmed. Lopez-Acevedo (2003) shows with Mexican linked employer-employee data that both employer and employees benefit from investments in training. Likewise, Rennison and Turcotte (2004) estimate with Canadian data a positive impact of (computer) training on wages and productivity controlling for various firm and worker characteristics. Also in this study, training has a larger impact on productivity than on wages, hinting at the sharing of costs and returns to training, as suggested by Becker (1964). Ballot, Fakhfakh and Taymaz (2001) use panels of French and Swedish firms to explore whether firms or workers benefit from training. They find that although the employees obtain significant benefits, firms obtain the largest part of the training rent. The authors conclude that firms can rationally invest in training and that hence, the hold-up problem leading to underinvestment in training by 
firms may be less severe than suggested by theoretical work (MacLeod and Malcomson, 1993).

Regarding the literature on German data, no study seems to concentrate on the training impact on productivity and wages simultaneously and to explore the issue of rent sharing. Closest to this analysis is Hempell (2003), where investments in information and communication technologies and firmsponsored training programmes are analysed. Using panel data from German service companies for the period 1994-1998, the impact of these investments on firm productivity is explored and compared to the impact on wage costs. I am not aware of any work where training is distinguished for low and high skilled workers to analyse whether there are differences in the impacts of training on wages and on productivity between skill groups. In the extension I explore whether there are differences for low and high skilled workers in the productivity effect of training and how the rent resulting from training is shared. Also, I test whether there are externalities of training participation, specifically spillover effects between skill groups. This is done by estimating the impact of training high skilled workers on average wages of low-skilled workers and by estimating the impact of training low-skilled workers on average wages of high skilled workers. The idea is that workers share their new knowledge with other workers (for example, high skilled workers teach the new knowledge to co-workers). Alternatively, high skilled workers might organise their work better after training. In that case, also low skilled workers profit from training participation of their team leaders or a foreman.

\section{Data Set}

Several types of data sets provide the opportunity to analyse wage and productivity effects of continuing training. Case studies are a good alternative if an indicator for workers individual productivity as well as their wage is available. Bartel (1995) uses data from the personnel record of a company to estimate the impact of training on wage growth and job performance. The drawback of this type of study is that it is not representative data and therefore, no inference can be made for the population. During the last years linked employer employee data sets became available for more and more countries. Here, the individual data set of workers includes a firm number for the employer. That way it can be identified which workers are employed by the same firm. Thus, firm specific effects can be controlled for and information about the firms' characteristics can be imputed from a firm level data set. Hence, this type of data set is first best to use when estimating productivity effects of continuing training.

Dearden, Reed, Van Reenen (2000) have shown, however, that it is also possible to use data aggregated on the industry level for analysing wage and productivity effects of continuing training. This approach is also taken here. The advantage of using aggregate data on the sectoral level is that external effects of training between firms in the same sector are included. Comparing the estimated coefficients with results from similar studies that conducted the 
analysis with firm data allows me to estimate the size of these external effects. I merge information from two sources to construct a panel data set. The main source is the German Micro-Census, a 1 percent sample of households in Germany. I aggregate information on the industry level and append industry data taken from the German National Accounts (NA). The compound panel data set consists of 58 industrial sectors in the cross section dimension and of seven years in the time series dimension, 1996 to 2002. In the Micro-Census, the survey questions on continuing training were completely changed from 1995 to 1996. For this reason I cannot use earlier years. Later years are not available yet. I use the following variables from the German National Accounts:

- gross value added,

- gross fixed capital formation,

- number of occupied persons,

- fixed assets as a proxy for capital.

A number of variables from the German Micro-Census are merged to this panel data set on an industry level. The main variable of interest is continuing training. In the years 1996 to 1998, two measures are available: participation in continuing training in the last four weeks and in the last year. The latter measure is the preferred one, because more employees indicate to participate in training during last year than during the last four weeks and hence the expected impact on sector productivity is also higher. Unfortunately, this measure of continuing training is not available for waves 1999 to 2002, so I have to choose the second best measure in order to use a longer time series of data. Hence, the variable of interest is the sectoral share of workers that took part in continuing training during four weeks prior to the survey. There are two important advantages of the data set. First, training participation is measured every year and it is possible to analyse the impact of training not only on current productivity but also on future productivity. Former work has shown that continuing training seems to have a lagged impact on productivity and I will include lagged training indicators in the analysis (see Bartel, 1995; Zwick, 2005). Second, the outcome variable, value added, includes also training costs. In contrast to many other studies, I can therefore make inferences on the impact of training on firm profitability. Other variables from the MicroCensus are:

- average net hourly wage (no information about gross wages) of all workers and separately for low and high skilled,

- average working time per sector,

- share of part-time contracts and share of temporary contracts, 
- qualification (I include the proportion of high skilled, which are those who have a university (or university of applied sciences) degree),

- enterprise size (I include the proportion of large firms with more than 1000 employees),

- job tenure (I use 7 variables indicating the share of employees per sector with a certain tenure),

- and, as a proxy for fluctuation in a sector, the proportion of workers per sector who changed the employer during last year (i.e. sectoral share of workers that change the job per year). (Expected) worker mobility determines the decision of firms to provide training and also that firms lose human capital if workers switch jobs (see, e.g., Garloff and Kuckulenz, 2006).

Additionally, I include the proportion of women and an indicator for East Germany to take into account differences in productivity and wages between east and west Germany (see Falk and Pfeiffer, 1998). The number of observations is 406 ( 58 sectors in seven years). For means and standard deviations of all variables used in the estimations see Table 6 in the appendix.

\section{Descriptive Statistics}

Participation in training varies between economic sectors, over time and by personal characteristics. Figure 1 shows participation in training per year. In the years 1996 to 2002 around 3 percent of the employees took part in training during four weeks prior to the survey. Training participation decreased in the late nineties and increased again slightly in 2001 and 2002. The share of workers that indicate to take part in on the job training (four weeks prior to the survey) is 5 percent in the British Labour Force Survey, so significantly higher than in the German Micro-Census (Dearden, Read and van Reenen, 2000).

There is considerably dispersion of training incidence across sectors. The share of training participants four weeks prior to the survey varies from zero for some sectors in some years (fishery, leather trade, nutrition trade, recycling and hotel and restaurant industry) to more than eight percent (data handling and databases, education and teaching, banking sector and insurance industry). A list of all sectors and the incidence of training, i.e. mean participation in training by sector, is given in the appendix (Table 7). Personal characteristics play a major role in determining training participation. Distinguishing between low (without tertiary education) and high skilled (with tertiary education) employees, it can be noted that the probability to take part in training is on average about 2.5 times higher for high than for low skilled workers. Training participation also varies widely by age. Young employees participate much more than older employees: around 5 percent of employees below 30 and less than 1 percent of employees above 55 take part in training. 
Figure 1: Average training participation in MZ 1996 - 2002

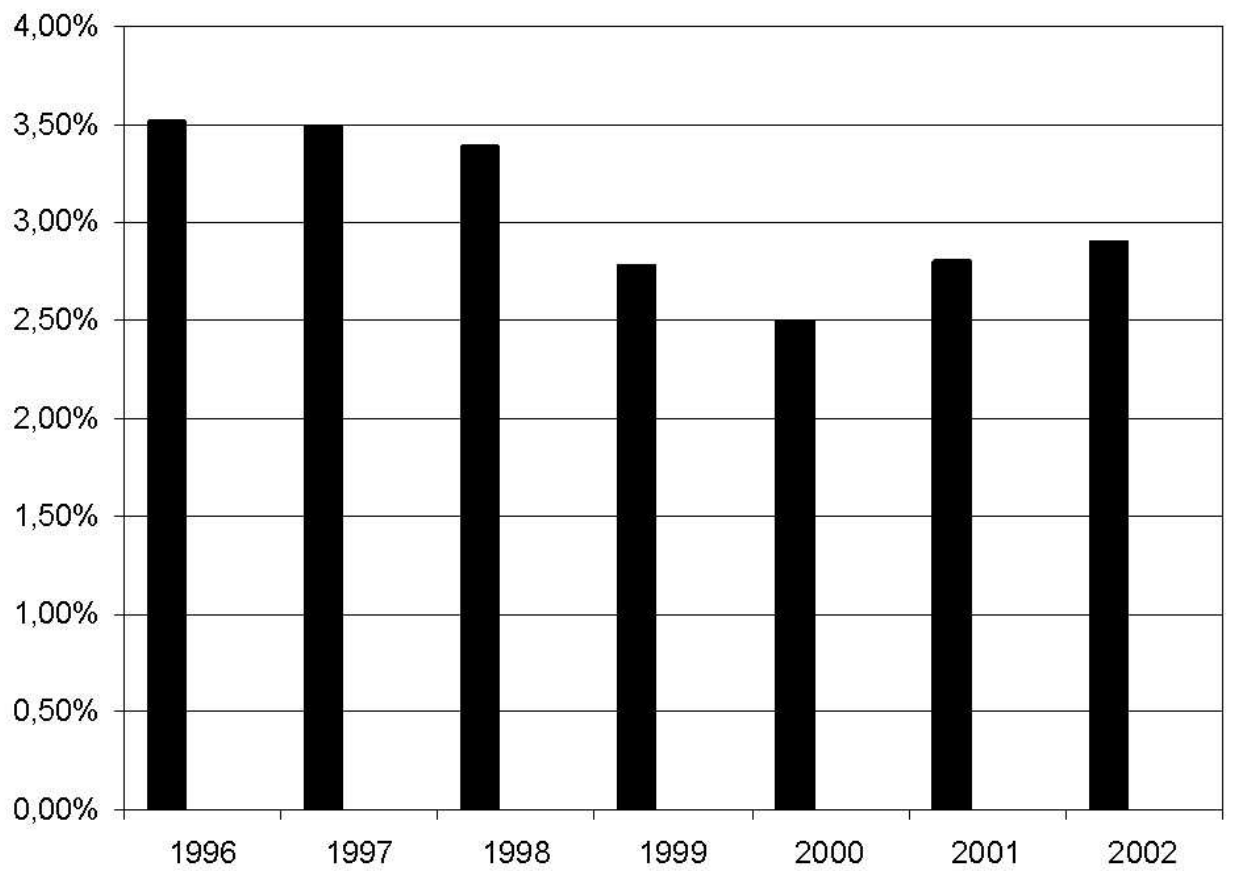

Source: Micro-Census, own estimation.

Using the median of training participation per sector, I divide the economic sectors into two groups, those with a high and those with a low incidence of training. The mean characteristics of these two groups of sectors are given in Table 1. Evidently, they differ also in other characteristics than the incidence of training. Economic sectors with a high incidence of training employ a higher share of high skilled and more women. In addition, firms in these sectors are larger and more profitable (have a higher value added) than average and employees have a higher average tenure and are paid a higher wage. Specifically, I am interested in the correlation between wages and productivity with training. Figures 2 and 3 show the bivariate relationship of training and productivity and of training and wages. A clear picture appears for the relation between training and wages, the correlation is strongly positive. The relationship between training and productivity is less clear, but the fitted line is pointing upward, showing a weaker positive relationship. In the following, I explore the nature of these relationships in more detail.

\section{Basic Model}

In the basic model I follow Dearden, Reed and van Reenen (2000 and 2005) and estimate the impact of the sectoral average training participation on average wage and productivity. In the extension, in contrast, I distinguish between low and high skilled workers and use average values for each skill 
Table 1: Sector means for low and high training intensive sectors

\begin{tabular}{lcc}
\hline Variables & LOW & HIGH \\
\hline Hourly wage & 16.36 & 20.00 \\
Number employed & 9331.96 & 10435.42 \\
Value added & 23.21 & 43.54 \\
Investments & 4.09 & 11.21 \\
Capital & 32.45 & 35.39 \\
Training & 0.02 & 0.04 \\
Working-hours & 38.27 & 36.51 \\
Part-time & 0.17 & 0.20 \\
Job change & 0.11 & 0.09 \\
Large firms & 0.18 & 0.26 \\
High skilled & 0.12 & 0.33 \\
Women & 0.37 & 0.49 \\
Temporary contract & 0.05 & 0.08 \\
Tenure 0-4 & 0.39 & 0.33 \\
Tenure 5-9 & 0.22 & 0.21 \\
Tenure 10-14 & 0.12 & 0.14 \\
Tenure 15-19 & 0.07 & 0.09 \\
Tenure 20-29 & 0.11 & 0.14 \\
Tenure 30-39 & 0.05 & 0.05 \\
Tenure 40 and above & 0.01 & 0.01 \\
Age17-20 & 0.02 & 0.01 \\
Age21-25 & 0.07 & 0.07 \\
Age26-30 & 0.12 & 0.12 \\
Age31-35 & 0.16 & 0.15 \\
Age36-40 & 0.15 & 0.16 \\
Age41-50 & 0.26 & 0.28 \\
Age51-65 & 0.22 & 0.22 \\
\hline Re & 80 - &
\end{tabular}

Remark: Sectors are divided in two groups of equal size using the median of training frequency per sector. This table shows the mean characteristics of these two groups. 
Figure 2: Training and productivity

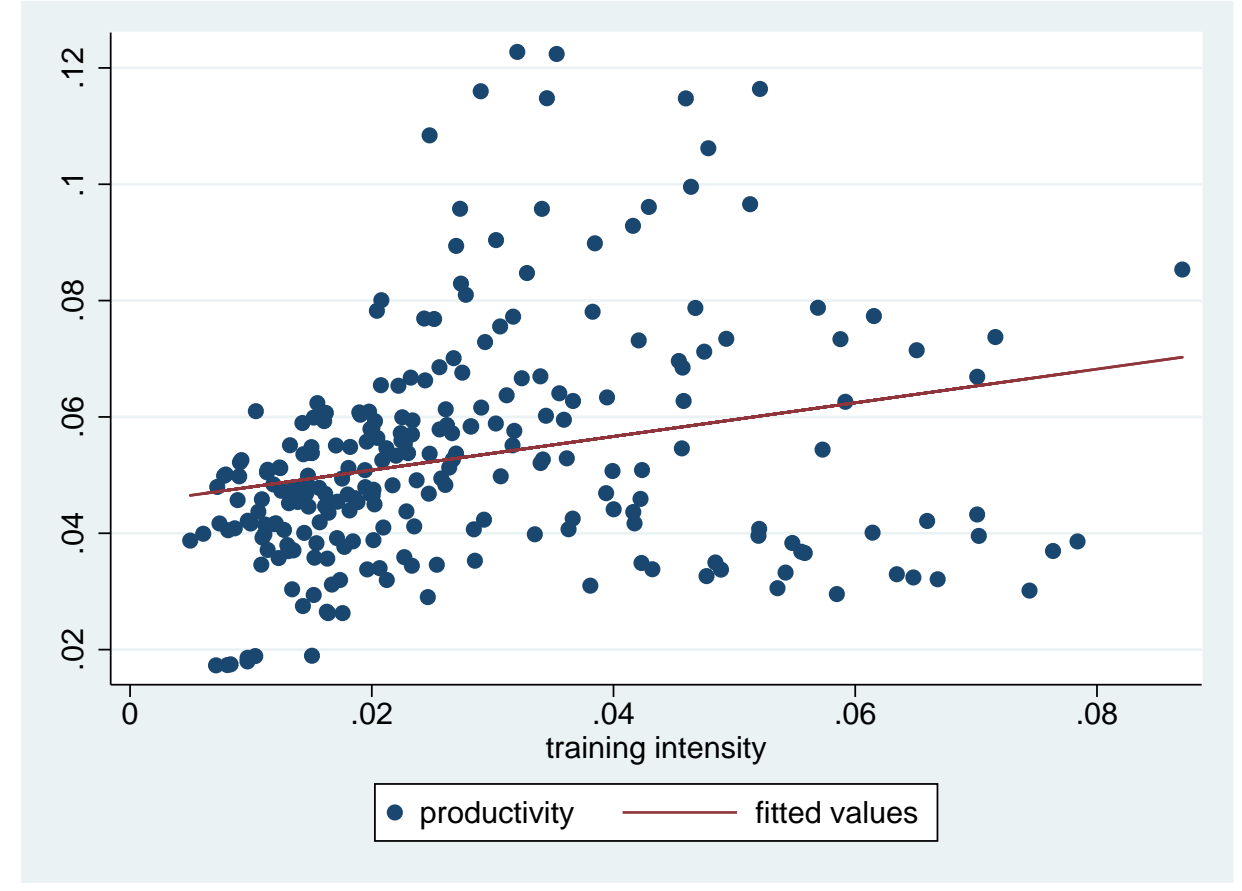

Remark: Scatterplot of value added per worker and the frequency of training per sector.

group.

\section{$5.1 \quad$ Estimation Strategy}

In order to quantify the impact of continuing training on wages and productivity, I use a simple Cobb-Douglas production function following Bartel (1995), Black and Lynch (2001) and Dearden, Reed and van Reenen (2000):

$$
Q=A L^{\alpha} K^{\beta},
$$

where $Q$ is value added, $A$ is a Hicks neutral efficiency parameter, $L$ is effective labour, and $K$ is capital. Assuming that effective labour improves with training, effective labour can be written as:

$$
L=N^{U}+\gamma N^{T}
$$

where $N^{U}$ are untrained and $N^{T}$ are trained workers and hence, the total number of workers $N$ is $N=N^{U}+N^{T}$. Trained workers are expected to be more productive than untrained workers and, hence, $\gamma>1$. Substituting equation 2 into 1 gives:

$$
Q=A\left(N^{U}+\gamma N^{T}\right)^{\alpha} K^{\beta}
$$

which can be rewritten as

$$
Q=A(1+(\gamma-1) \text { Train })^{\alpha} N^{\alpha} K^{\beta},
$$


Figure 3: Training and hourly wage

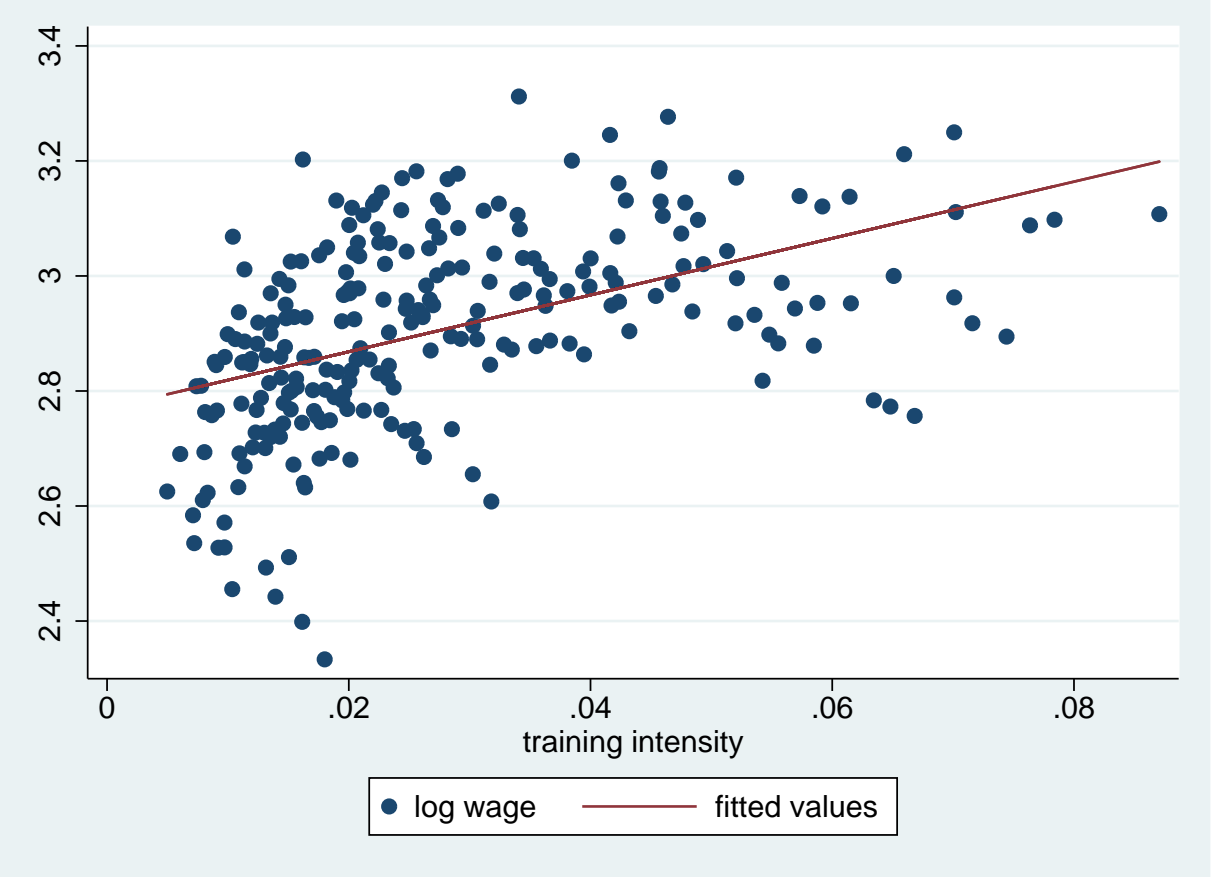

Remark: Scatterplot of average log wage and the frequency of training per sector.

where Train $=\frac{N^{T}}{N}$. If $(\gamma-1)$ Train is small, the approximation $\ln (1+x)=x$ can be used and the production function can be rewritten in logarithmic form as:

$$
\log Q=\log A+\alpha(\gamma-1) \text { Train }+\alpha \log N+\beta \log K .
$$

If the industry exhibits constant returns to scale, i.e. $\alpha+\beta=1$, then (4) can be written in terms of labour productivity:

$$
\log \frac{Q}{N}=\log A+(1-\beta)(\gamma-1) \text { Train }+\beta \log \frac{K}{N} .
$$

In case trained workers are no more productive than untrained, i.e. $\gamma=1$, the coefficient of Train will be zero. A large number of other variables that are assumed to have systematic influences on productivity are captured in A. Notably, I include proxies for human capital (education, age, tenure), working hours, turnover rate, gender, regional composition, proportion of large firms and temporary contracts. Additionally, I include year dummies to control for year fixed effects.

Instrumental variables that are correlated with training but uncorrelated with productivity or GMM techniques are two commonly used approaches in order to take endogeneity into account. Since valid external instruments are difficult to find, I choose recent GMM techniques that exploit information in the 
levels and in difference equations (for an intuitive guide to panel data models, refer to Bond, 2002; for an application of GMM estimation to production functions, see Blundell and Bond, 2000). The estimation strategy controls for observed time invariant sector heterogeneity by using system GMM panel regressions. It simultaneously controls for endogeneity of continuing training by using internal instrumental variables. The system GMM estimator proposed by Arellano and Bover (1995) avoids the poor finite sample properties of the simple within estimator or the simple GMM estimator, which take first differences to eliminate unobserved firm-specific effects or use lagged internal instruments to correct for simultaneity in the first-difference equations. It is problematic to use lagged levels as instruments because they are usually only weakly correlated with the subsequent first differences of these variables and therefore have weak explanatory power (Blundell and Bond, 2000). To overcome this problem, the system GMM estimator uses the lagged first differences as instruments for the equations in first differences, assuming that the internal instruments are correlated with current values but independent of the error term. As with any valid instrumental variables strategy, this estimator corrects for any bias arising from measurement error in the dependent variable and the regressors. I report the Hansen test for overidentification of the model and serial correlation tests since the GMM estimator depends on the absence of second order serial correlation in the error term (Dearden, Reed and Van Reenen, 2000). A negative first order correlation, in contrast, is consistent with the assumptions of the model. Summarising, the system GMM estimator avoids inconsistencies incurred by unobserved heterogeneity and simultaneity of the choice of training, capital, labour, wages and output (Blundell and Bond, 1999; Black and Lynch, 2001; Hempell, 2002; Zwick, 2003; Gürtzgen, 2005). Hence, the resulting basic empirical model for the logarithm of value added (productivity) per worker $y_{i t}$ of sector $i$ in period $t$ is:

$$
y_{i t}=\beta_{1} \operatorname{Train}_{i t}+\beta_{3} k+\beta_{2} x+\eta_{i}+\epsilon_{i t},
$$

where $k$ represents the logarithm of capital per worker, $x$ is a vector of explanatory variables, $\eta_{i}$ denotes time-invariant unobserved sector-specific effects impacting productivity and the error term $\epsilon_{i t}$ is assumed to be asymptotically normally distributed. To account for aggregation bias ${ }^{1}$, data is weighted by the number of employed in each economic sector. Similarly, I run wage regressions, where I explain average wage $w_{i t}$ in sector $i$ in period $t$ by exactly the same inputs that enter the production function:

$$
w_{i t}=\beta_{1} \operatorname{Train}_{i t}+\beta_{3} k+\beta_{2} x+\eta_{i}+\epsilon_{i t} .
$$

\footnotetext{
${ }^{1}$ I expect that the fixed effects will control for much of the problem of aggregation biases in industry level data. Also, I take logs of means and not the means of logs when aggregating. As long as the higher order moments of the distributions are constant over time in an economic sector, then they will be captured by a fixed effect. If they evolve at the same rate across industries they will be picked up by time dummies (see also Dearden, Reed and Van Reenen, 2000).
} 
With this specification, I can assess and compare the wage and productivity impact of continuing training to have a first idea how the training rent is shared between employers and employees.

\subsection{Empirical Results}

First, I pool the data and estimate productivity and hourly wage regressions with simple static pooled Ordinary Least Squares (POLS) to have a benchmark result. Results are shown in Table 2. The training coefficient is significantly positive in the hourly wage regression (second column) and positive but insignificant in the productivity regression (first column). The higher R-squared in the second column suggests that the variation in average hourly wages per sector is better explained by the covariates than the variation in sectoral productivity. A high share of high skilled and investments are positively related with productivity and with hourly wages. The share of women and of firms per sector located in East Germany are negatively related with hourly wages but not with productivity. There is no significant relation between age and productivity but the share of young workers is negatively related with hourly wages. This hints at the existence of seniority wages (Lazear, 2000). Average tenure in a sector and the indicator for fluctuation are (weakly) negatively related with wages and not significantly related with productivity. The share of employees with temporary contracts is higher in sectors that are less productive and pay lower hourly wages. Labour and capital are positively related with productivity (although capital is not significant in the estimation) and are insignificant in the wage regressions. Firm size and hourly wages are significantly positively correlated. The productivity regression shows no significant relation between the share of large firms and the outcome variable.

In addition, I estimate four different models for the productivity regression as well as for the hourly wage regression with system GMM. ${ }^{2}$ In the various models I vary the number of regressors and the exogeneity assumptions. The first model is the most restrictive one, assuming endogeneity of capital and labour and exogeneity of all other variables. The second model assumes endogeneity of capital, labour and training. The third and fourth model are the least restrictive models, allowing for endogeneity of all regressors except for the regional indicator and the time dummies. In the second and the fourth model, I add dummies indicating the share of age groups per sector as additional regressors. The specific assumptions of the empirical models are described in the tables together with the results. The system GMM results of the productivity regression are reported in Table 2 and those of the hourly wage regression are reported in Table 3 . Included in the tables are also the Arellano-Bond tests for autocorrelation. AR(1) is expected in first

\footnotetext{
${ }^{2}$ Alternatively, I also used the first-difference GMM estimator for the calculations but I obtained much more reasonable results using the system GMM estimator. Specifically, I find that the additional instruments used in the system GMM estimator are both valid and informative in this context.
} 
Table 2: POLS

\begin{tabular}{|c|c|c|c|c|}
\hline variables & \multicolumn{2}{|c|}{ Productivity regression } & \multicolumn{2}{|c|}{ Hourly wage regression } \\
\hline & coef. & t-values & coef. & t-values \\
\hline Training & 2.83 & $(1.42)$ & 0.79 & $(1.90)^{*}$ \\
\hline ln capital & 0.02 & $(0.23)$ & -0.02 & $(-1.28)$ \\
\hline ln investments & 0.44 & $(6.22)^{* * *}$ & 0.04 & $(3.17)^{* * *}$ \\
\hline Large firms & 0.56 & $(0.87)$ & 0.22 & $(1.96)^{*}$ \\
\hline Temporary contract & -4.72 & $(-3.93)^{* * *}$ & $-0,94$ & $(-4.02)^{* * *}$ \\
\hline ln labour & 0.07 & $(2.12)^{* *}$ & 0.00 & $(-0.60)$ \\
\hline Job change & -1.00 & $(-0.64)$ & -0.61 & $(-2.08)^{* *}$ \\
\hline High skilled & 0.99 & $(1.89)^{*}$ & 0.77 & $(7.94)^{* * *}$ \\
\hline Women & -0.07 & $(-0.19)$ & -0.34 & $(-6.77)^{* * *}$ \\
\hline Tenure 0-4 & \multicolumn{2}{|c|}{ reference } & \multicolumn{2}{|r|}{ reference } \\
\hline Tenure 5-9 & 1.29 & $(1.22)$ & 0.01 & $(0.03)$ \\
\hline Tenure $10-14$ & 0.30 & $(0.20)$ & -0.35 & $(-1.30)$ \\
\hline Tenure $15-19$ & 1.43 & $(1.18)$ & 0.30 & $(1.17)$ \\
\hline Tenure $20-29$ & -1.76 & $(-0.84)$ & 0.12 & $(0.54)$ \\
\hline Tenure $30-39$ & -1.37 & $(-0.55)$ & -0.62 & $(-1.98)^{*}$ \\
\hline Tenure $40-51$ & -9.71 & $(-1.61)$ & -2.39 & $(-2.77)^{* * *}$ \\
\hline Age $17-20$ & \multicolumn{2}{|c|}{ reference } & \multicolumn{2}{|r|}{ reference } \\
\hline Age $21-25$ & 6.23 & $(0.84)$ & 1.92 & $(1.83)^{*}$ \\
\hline Age $26-30$ & 1.12 & $(0.18)$ & 0.71 & $(0.70)$ \\
\hline Age $31-35$ & 2.79 & $(0.49)$ & 1.31 & $(1.27)$ \\
\hline Age $36-40$ & 0.90 & $(0.14)$ & 1.25 & $(1.19)$ \\
\hline Age $41-50$ & -0.12 & $(-0.02)$ & 1.23 & $(1.21)$ \\
\hline Age 51-65 & 4.92 & $(0.74)$ & 1.72 & $(1.72)^{*}$ \\
\hline Intercept & -2.76 & $(-0.48)$ & 1.95 & $(2.05)^{* *}$ \\
\hline Observations & \multicolumn{2}{|r|}{361} & \multicolumn{2}{|r|}{364} \\
\hline Sectors & \multicolumn{2}{|r|}{52} & \multicolumn{2}{|r|}{52} \\
\hline R-squared & \multicolumn{2}{|r|}{0.8325} & \multicolumn{2}{|r|}{0.8989} \\
\hline
\end{tabular}


differences but higher-order autocorrelation indicates that some lags of the dependent variable, which might be used as instruments, are in fact endogenous, thus, bad instruments. I also report a test of over-identifying restrictions, i.e. whether the instruments as a group appear exogenous. For all models, test statistics show that the models are well specified. I also test with Hansen difference statistics whether additional moment conditions are fulfilled. Testing the specification with endogenous capital, labour, and training against the more restrictive specification where training is exogenous, a low p-value indicates that the training variable is endogenous. In contrast, testing the other additional regressors for exogoneity, the Hansen difference statistics suggest that additional moment conditions are fulfilled. Hence, the second model is the preferred specification but I nevertheless report the results of all four specifications. 


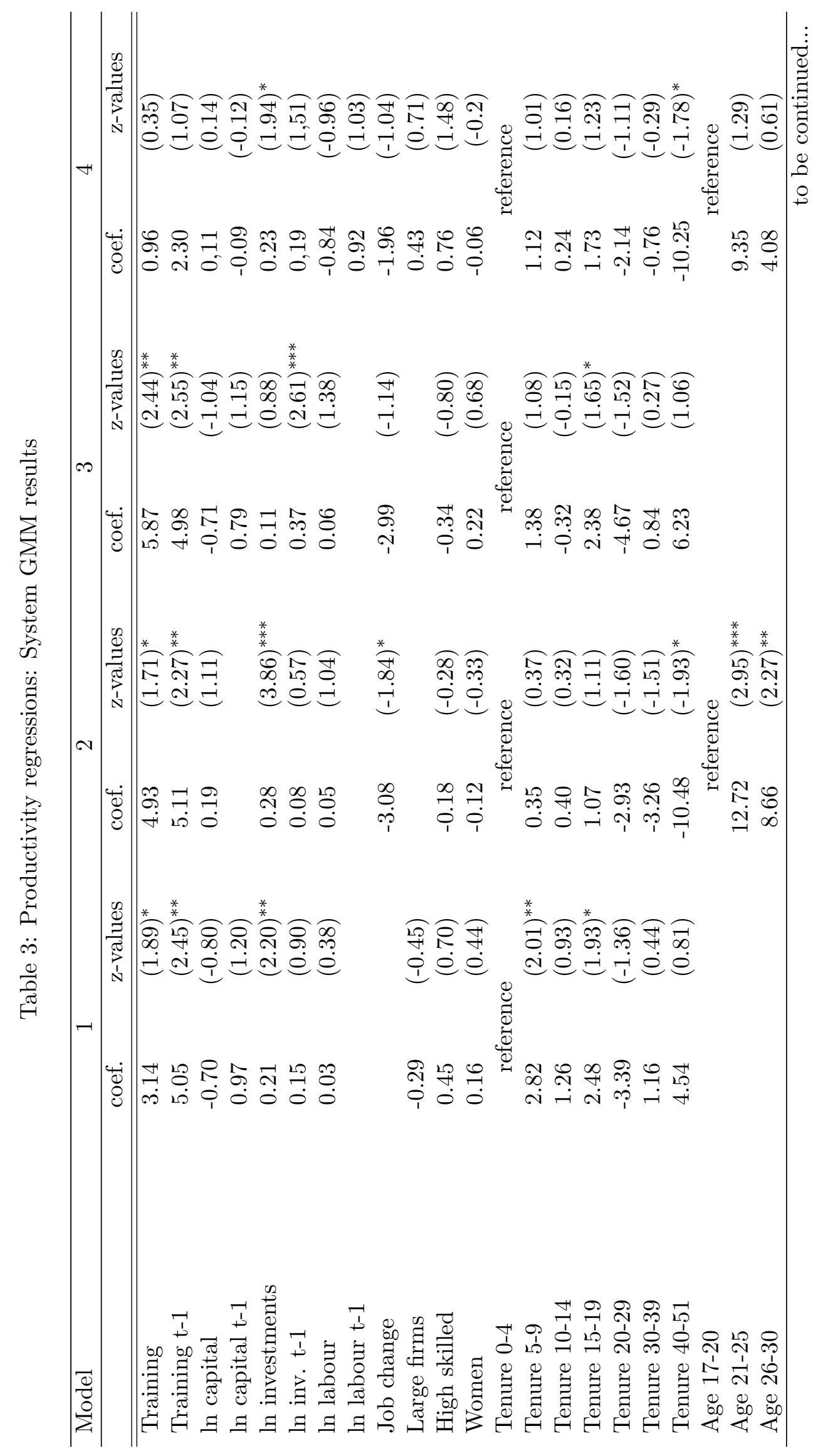




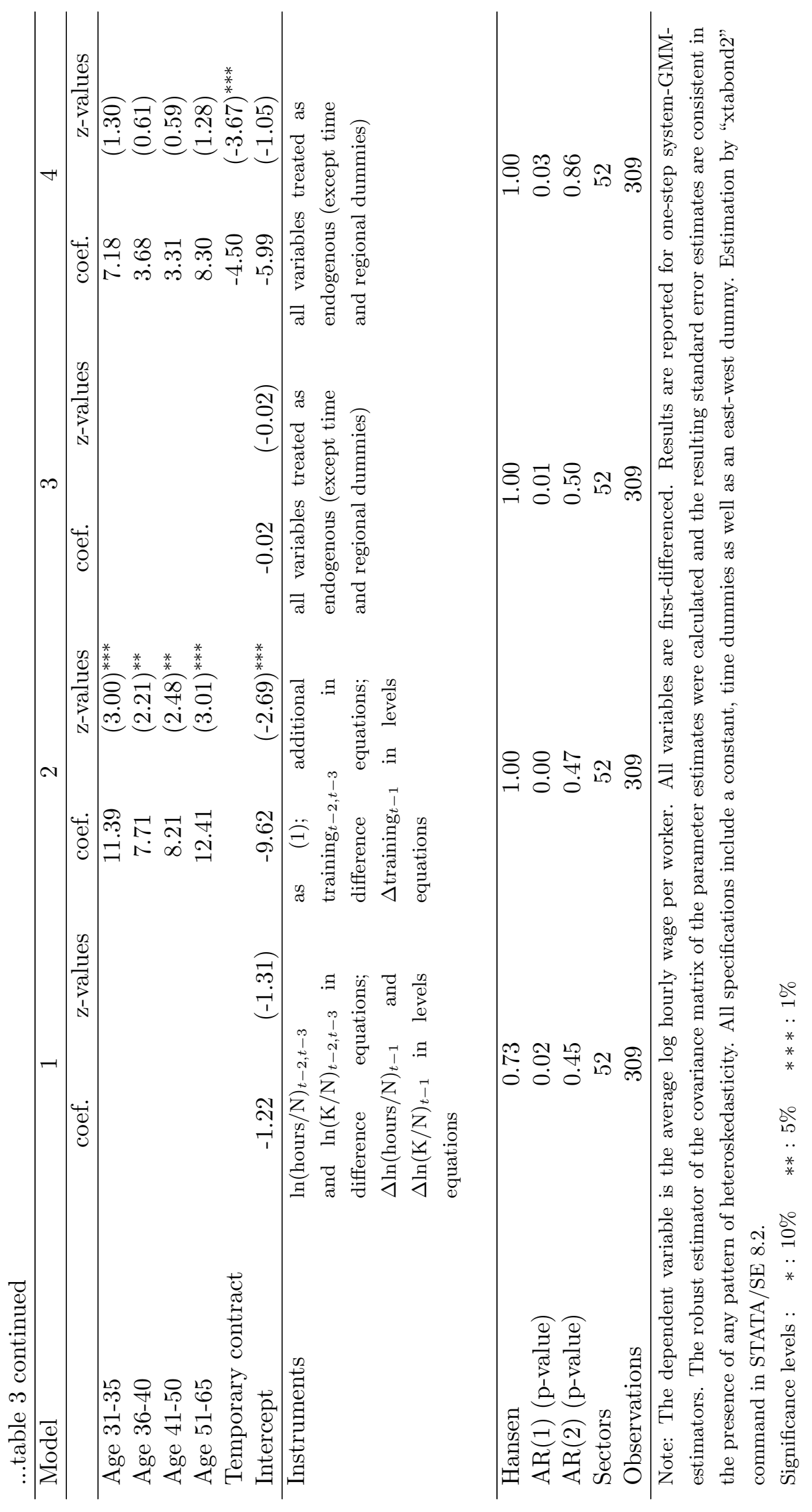




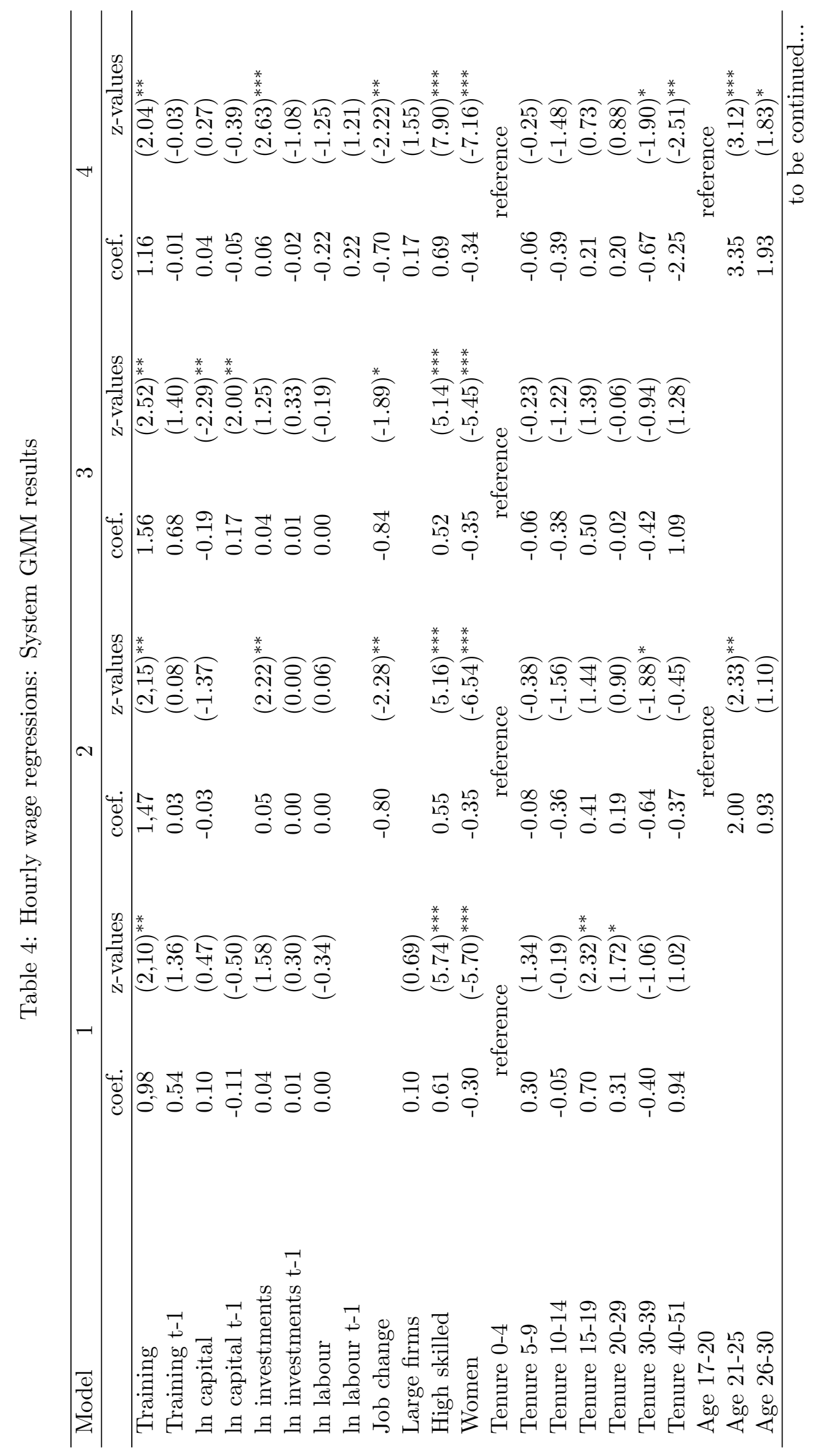




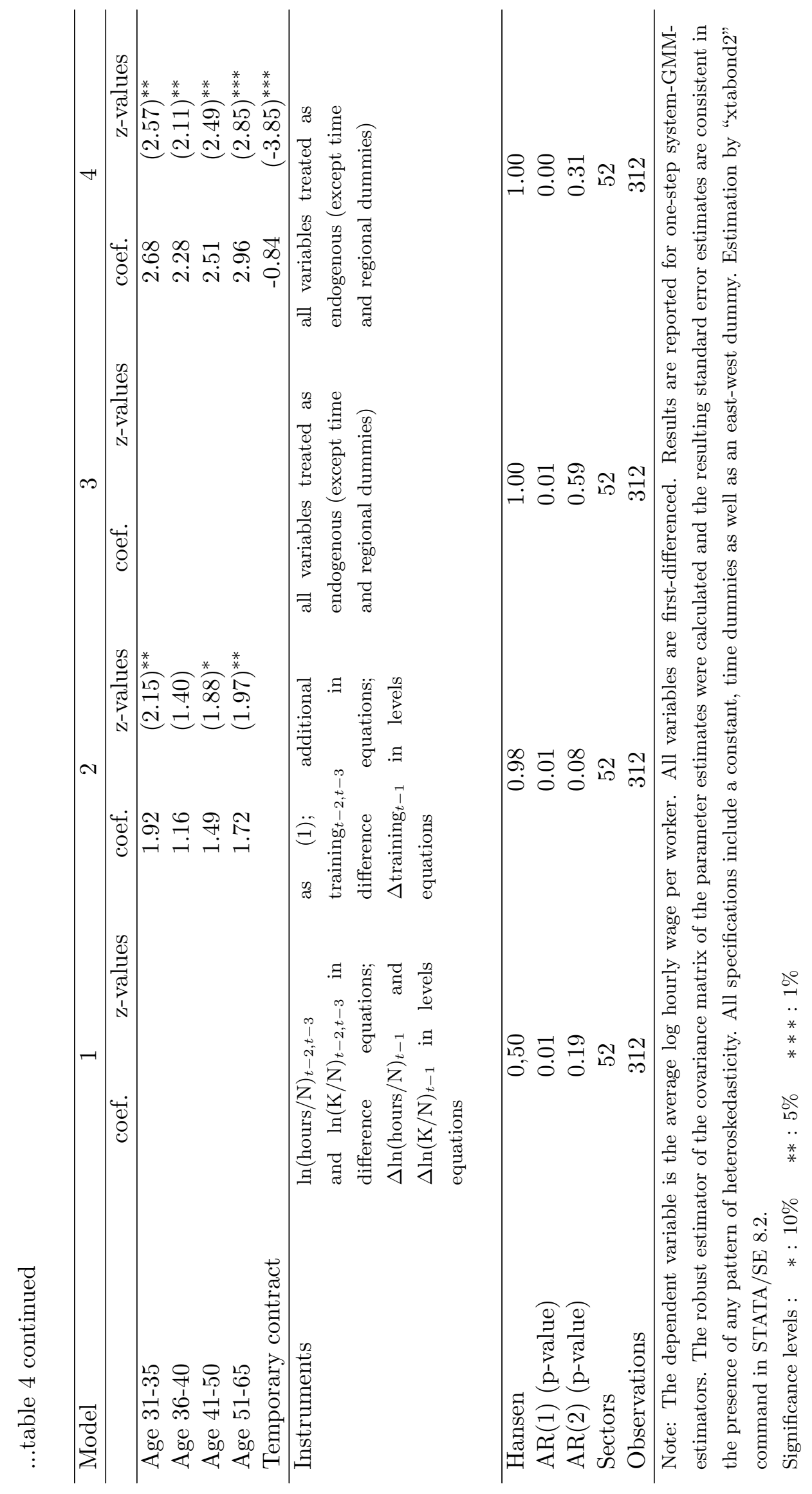


Table 3 contains the results of the productivity regressions. Like in the pooled OLS regression, the estimated training coefficient is positive. In the system GMM regressions, the coefficient of training is, however, significant. Both contemporaneous training and lagged training have a positive and significant impact on productivity. That is, those sectors with high participation in continuing training achieve a higher value added per worker in the year where training took place and also in the next year. Only in the last model, the impact of training on productivity is insignificant. The model is probably overloaded with regressors and instruments. Thus, there remain hardly any significant coefficients. Capital and labour are positive but not significant in the regressions. Investments per worker have a positive and significant impact on sectoral productivity and fluctuation proxied by job changes within a sector as well as the share of temporary contracts have a negative influence on sector productivity. ${ }^{3}$ Evidence for average tenure in a sector is mixed but suggesting that low average tenure per sector has a positive impact on productivity. Contrasting the results from pooled OLS regressions, the age dummies are positive and significant in the system GMM regressions. Therefore, a higher share of older workers per sector seems to have a positive impact of productivity.

Results from the hourly wage regressions are given in Table 4. Like in the pooled OLS regression, the estimated training coefficient is positive and significant. While in the productivity regression, both contemporaneous and lagged training have a significant impact on productivity, in the hourly wage regressions, only contemporaneous training is significant. Investments (lagged and contemporaneous) have a positive influence on wages similar to the impact of investments on productivity. The impact of capital on wages seems to be insignificant. Only in Model 3, there is a negative impact of contemporaneous capital intensity on wages and a positive impact of lagged capital intensity on wages. Fluctuation in a sector as well as the share of contemporary contracts have a negative influence on hourly wages (again similar to the results in the productivity regression). The share of high skilled workers and the share of women do not have any impact on sectoral productivity. In the wage regressions, these indicators are highly significant in all models. A large share of high skilled workers is related to high hourly wages and a high share of women in a sector is related to low average wages in a sector. Again, the evidence for tenure is rather mixed. As in the productivity regression, the age variables are positive and significant; i.e. seniority wages are prevalent, a high share of older workers is related to high average wages in a sector.

As noted by Dearden, Reed and Van Reenen (2000), grouping of data on the industry level has the advantage that spillovers of continuing training are included in the productivity effect. For example, if workers with higher human capital are more likely to generate new ideas and innovations which may spill to other employees even in other firms (within the industry), micro-

\footnotetext{
${ }^{3}$ Sectoral fluctuation includes job changes within the sector and entrees and from other sectors.
} 
level estimation underestimates the true impact of continuing training because externalities to human capital acquisition are not taken into account. In a non-technical review of the empirical evidence on the returns to education for the individual, the firm and the economy at large, Blundell, Dearden, Meghir and Sianesi (1999) note that there exists hardly any empirical evidence on the returns to training including externalities.

Similar studies with German data using firm level survey data also find positive effects of training on productivity. Zwick (2004 and 2006) estimates with similar econometric methods a positive training coefficients close to 1 . The estimated coefficients here are higher and therefore suggest that knowledge spillovers between firms in the same sector exist. Of course, not the entire difference in coefficients has to reflect positive externalities. Differences in the data set used can also explain differences in estimation results as is shown in Kuckulenz (2006).

\section{Differentiation between Low and High Skilled}

In an extension of the basic model based on Dearden, Reed and Van Reenen (2000 and 2005), I allow for worker heterogeneity in the basic production function. This allows me to estimate the impact of training on productivity for low and high skilled workers separately. Additionally, I estimate the impact of training on own average wages for both skill groups separately and on the average wage of the other group. This may hint to the existence of externalities between workers or, more specifically, between different skill groups. If, for example, training high skilled employees exhibits a positive external effect because they transmit the new knowledge to the low skilled employees, there could be a positive impact of training high skilled workers on wages of low skilled workers.

\subsection{Extension of the Model}

For the extension I use the same simple Cobb-Douglas production function:

$$
Q=A L_{L}^{\alpha} L_{H}^{\beta} K^{\gamma}
$$

Here, $L_{L}$ is effective low skilled labour and $L_{H}$ is effective high skilled labour. Assuming that effective labour is improved by training, it can be written as

$$
L_{L}=N_{L}^{U}+\delta N_{L}^{T}
$$

and

$$
L_{H}=N_{H}^{U}+\epsilon N_{H}^{T},
$$

where $N_{L}^{U}$ are untrained low skilled workers, $N_{L}^{T}$ are trained low skilled workers, $N_{H}^{U}$ are untrained high skilled workers, $N_{H}^{T}$ are trained high skilled workers and the total number of workers $N$ is $N=N_{L}+N_{H}$ comprising low skilled workers $N_{L}, N_{L}=N_{L}^{U}+N_{L}^{T}$, and high skilled workers $N_{H}, N_{H}=N_{H}^{U}+N_{H}^{T}$. I expect that trained workers are more productive than untrained workers 
and hence $\delta>1$ and $\epsilon>1$. Substituting equations (7) and (8) into (6) gives

$$
Q=A\left(N_{L}^{U}+\delta N_{L}^{T}\right)^{\alpha}\left(N_{H}^{U}+\epsilon N_{H}^{T}\right)^{\beta} K^{\gamma} .
$$

I can rewrite (9) as

$$
\begin{aligned}
Q & =A\left(N_{L}-N_{L}^{T}+\delta N_{L}^{T}\right)^{\alpha}\left(N_{H}-N_{H}^{T}+\epsilon N_{H}^{T}\right)^{\beta} K^{\gamma} \\
& =A\left(N_{L}+(\delta-1) N_{L}^{T}\right)^{\alpha}\left(N_{H}+(\epsilon-1) N_{H}^{T}\right)^{\beta} K^{\gamma} \\
& =A\left(N_{L}+(\delta-1) \operatorname{Train}_{L} N_{L}\right)^{\alpha}\left(N_{H}+(\epsilon-1) \operatorname{Train}_{H} N_{H}\right)^{\beta} K^{\gamma},
\end{aligned}
$$

where $\operatorname{Train}_{H}=\frac{N_{H}^{T}}{N_{H}}$ is the proportion of high skilled trained workers in all high skilled workers and $\operatorname{Train}_{L}=\frac{N_{L}^{T}}{N_{L}}$ is the proportion of low skilled trained workers in all low skilled workers. Rewriting yields

$$
Q=A\left(1+(\delta-1) \operatorname{Train}_{L}\right)^{\alpha}\left(1+(\epsilon-1) \operatorname{Train}_{H}\right)^{\beta} K^{\gamma} N_{L}^{\alpha} N_{H}^{\beta} .
$$

If $(\delta-1) \operatorname{Train}_{L}$ and $(\epsilon-1) \operatorname{Train}_{H}$ are small, the approximation $\ln (1+x)=x$ can be used and the production function can be rewritten in logarithmic form as

$$
\begin{aligned}
\log Q= & \log A+\alpha \log \left(1+(\delta-1) \text { Train }_{L}\right)+\beta \log \left(1+(\epsilon-1) \text { Train }_{H}\right)+\gamma \log K \\
& +\alpha \log N_{L}+\beta \log N_{H} \\
= & \log A+\alpha(\delta-1) \text { Train }_{L}+\beta(\epsilon-1) \text { Train }_{H}+\gamma \log K+\alpha \log N_{L}+\beta \log N_{H} .
\end{aligned}
$$

Rewritten in per capita terms (substract $\log N$ from both sides)gives

$$
\begin{aligned}
\log \frac{Q}{N}= & \log A+\alpha(\delta-1) \text { Train }_{L}+\beta(\epsilon-1) \text { Train }_{H} \\
& +\gamma \log K+\alpha \log N_{L}+\beta \log N_{H}-\log N .
\end{aligned}
$$

For the case of constant returns to scale $(\alpha+\beta+\gamma=1)$,

$$
\begin{aligned}
\log \frac{Q}{N}= & \log A+\alpha(\delta-1) \operatorname{Train}_{L}+\beta(\epsilon-1) \operatorname{Train}_{H} \\
& +\gamma \log K+\alpha \log N_{L}+\beta \log N_{H}-(\alpha+\beta+\gamma) \log N
\end{aligned}
$$

and

$$
\begin{aligned}
\log \frac{Q}{N}= & \log A+\alpha(\delta-1) \operatorname{Train}_{L}+\beta(\epsilon-1) \text { Train }_{H} \\
& +\gamma \log \frac{K}{N}+\alpha \log \frac{N_{L}}{N}+\beta \log \frac{N_{H}}{N} .
\end{aligned}
$$

If trained workers are as productive as untrained workers, i.e. $\delta=1$ and $\epsilon=1$, then the coefficients of $\operatorname{Train}_{H}$ and $\operatorname{Train}_{L}$ will be zero. 


\subsection{Empirical Results}

To compare productivity effects with wage effects of training low and high skilled workers, I again estimate wage regressions using the same specification as in the productivity equation. I use the average wage of low and high skilled workers separately to estimate the effect of training for low and for high skilled workers on their own wage and on wages of the other skill group. That way, I am able to test for differences in rent sharing between firms and high skilled employees and firms and low skilled employees. As derived from the theoretical considerations, I suspect that high skilled employees are able to capture a higher share of the training rent than low skilled employees. Also, I can find evidence whether differences in the wage mark up between low and high skilled workers are due to differences in the productivity impact. Alternatively, high and low skilled workers might take part in different types of training, leading to different productivity impacts. In addition, the bargaining power is important. Even if the productivity impact of training is similar for both skill groups, differences in the impact on wages can arise if one skill group has more bargaining power in capturing (part of) the training rent.

Additionally, I test whether there are externalities of continuing training between skill groups. In that case, the social return would differ from the individual return to continuing training and might justify government intervention. For example, when high skilled workers receive training, this may not only raise their own productivity but also the productivity of low skilled and hence increase wages for both groups. In that case, training of high skilled workers contains a positive externality because there are positive spillovers from training on the productivity of low skilled.

In the first column of Table 5, estimates of the influence of low and high skilled training participation on average wages of low skilled is presented. The estimated coefficients are insignificant. In contrast, lagged training participation of high skilled increases the average of high skilled and training of low skilled does not impact the average wage of high skilled workers (second column of Table 5). In the third column, the impact of low and high skilled workers' training participation on value added per worker is shown. The results suggest that only training of low skilled workers has an impact on productivity, while training of high skilled workers has no significant influence. Summing up, it seems that training low skilled workers increases productivity and that firms capture the gain from training since value added is increased by training but low skilled workers do not receive a wage mark up after training. For high skilled workers, results suggest the contrary. There seems to be also a rent to share after training. In the case of high skilled employees participating in training, not the firms gain from the productivity increase, but the high skilled workers receive a wage mark up. 
Table 5: System GMM with two skill groups: Wage and productivity regressions

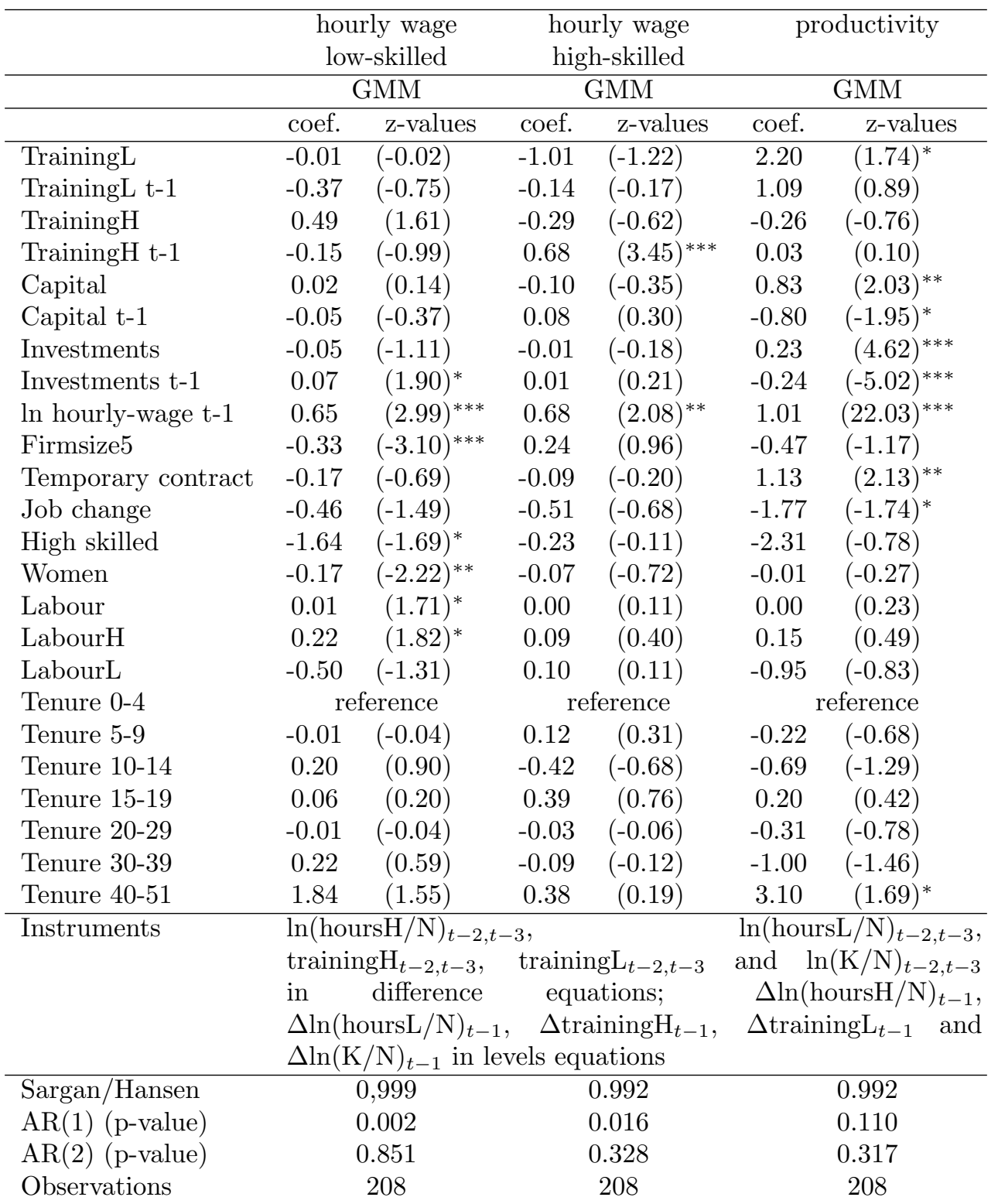

Note: The dependent variable in the first column is the average log hourly wage for low and high skilled in the second and third column, and value added per worker in the fourth column. All variables are first-differenced. Results are reported for one-step system-GMMestimators. The robust estimator of the covariance matrix of the parameter estimates were calculated and the resulting standard error estimates are consistent in the presence of any pattern of heteroskedasticity. All specifications include a constant, time dummies as well as an east-west dummy.

Estimation by "xtabond2" command in STATA/SE 8.2.

Significance levels : $\quad *: 10 \% \quad * *: 5 \% \quad * * *: 1 \%$ 


\section{Conclusion}

The analyses in this paper provide evidence for the existence of rent sharing between firms and workers. On average, both employers and employees profit from the investment in human capital since sectoral training intensity increases both sectoral value added per worker as well as sectoral average hourly wages. The productivity effect of training is about three times higher than the wage effect. In addition, training has a lagged impact on productivity but not on wage levels.

The basic model is extended to differentiate between low and high skilled workers. The results from the analysis with two types of workers are in line with results in Kuckulenz and Zwick (2003). High skilled workers receive a wage mark up from participating in training while low skilled workers, on average, experience no wage effect of training. There seems to be a positive impact of training low skilled workers on productivity but no impact of training high skilled workers. This might be explained by the either high training costs (which decrease value added) or, more likely, by the small number of high skilled workers. With the data on sector level we cannot measure the productivity increase of only one skill group but only of the whole sector.

The analysis on a sectoral level allows the estimation of external effects between workers and firms. In particular, I estimate the impact of training one skill group on wages of the other group. The idea is that high skilled workers might transmit knowledge acquired in training to low skilled workers or they may organise work procedures more efficiently or improve production processes after training which affects also low skilled workers. In the empirical analysis with aggregated data I find no evidence for external effects of training between skill groups.

Since the estimation of the impact of training on productivity is on a sectoral level, it includes spillover effects between firms in the same sector. Such spillover effects are existent if firms learn with each other, if they copy from each other or if job changes between firms in the same sector induce human capital to be transmitted. The impact of training on productivity estimated here is much higher than calculated effects of training on productivity with firm level data. Zwick (2004 and 2006), for example, finds an impact of training on firm productivity that is only one third of the impact on sector productivity estimated in this study. Even though both data sets used are representative for Germany, the difference in the coefficient can be (partly) explained by the difference in the data sets used. Nevertheless, the results suggests that external effects of continuing training exist in Germany. This is in line with the findings of Dearden, Reed and Van Reenen (2000 and 2005). The training measure used here is crude, including all types of training. I cannot distinguish whether the training measures for high skilled are different from training for low skilled. Given previous evidence (see Kuckulenz and Zwick, 2005, and Kuckulenz, 2006), it is likely that the type of training differs between skill groups. This could also explain why the impact of training varies 
between skill groups as suggested in the extension. While low skilled workers participate often in internal and firm-specific training, high skilled workers often take part in external training that is more general and where the new knowledge would be useful also in other firms. This is in line with the results in this paper: high skilled workers increase their general human capital in training and receive a wage mark up afterwards. In contrast, low skilled workers increase their firm specific human capital in continuing training and do not obtain a higher wage after training participation.

The analysis here is restricted to the training impact on wages and productivity. Other important aspects are not taken into account. It may well be that also low skilled workers profit from training participation even if they do not receive a wage mark up. Positive effects from training on job security and on satisfaction with the job are very likely. 


\section{References}

Acemoglu, D., And J. Angrist (2000): "How large are human capital externalities? Evidence from compulsary schooling laws," NBER Macroeconomics Annual, 9-59.

Alba-Ramirez, A. (1994): "Formal Training, Temporary Contracts, Productivity and Wages in Spain," Oxford Bulletin of Economics and Statistics, 56(2), 151-170.

Arai, M. (2003): "Wages, Profits, and Capital Intensity: Evidence from Matched Worker-Firm Data," Journal of Labor Economics, 21, 593-618.

Arellano, M., and O. Bover (1995): "Another Look at the InstrumentalVariable Estimation of Error-Components," Journal of Econometrics, 68, $29-51$.

Ballot, G., F. Fakhfakh, and E. Taymaz (2002): "Who benefits from training and R\&D: The firm or the workers? A study on panels of French and Swedish firms," Working papers, ERC - Economic Research Center, Middle East Technical University.

BARro, R. J. (2001): "Human capital and growth," American Economic Review, 91(2), 12-17.

Bartel, A. P. (1995): "Training, Wage Growth, and Job Performance: Evidence from a Company Database," Journal of Labor Economics, 13(3), 401-425.

Becker, G. S. (1964): Human Capital. Chicago: University of Chicago Press.

Black, S. E., And L. M. Lynch (2001): "How To Compete: The Impact Of Workplace Practices And Information Technology On Productivity," The Review of Economics and Statistics, 83, 434-445.

Blanchflower, D. G., A. J. Oswald, and P. SAnfey (1996): "Wages, Profits, and Rent-Sharing," The Quarterly Journal of Economics, 111(1), $227-251$.

Blundell, R. W., And S. R. Bond (2000): "GMM Estimation with Persistent Panel Data," Econometric Reviews, 19, 321-340.

Bond, S. R. (2002): "Dynamic Panel Data Models: A Guide to Micro Data Methods and Practice," Portuguese Economic Journal, 1, 141-162.

Boon, M., And B. van Der EiJken (1997): "Employee Training and Productivity in Dutch Manufacturing Firms," Statistics Netherlands research paper 9716 . 
Booth, A. L., M. Francesconi, and G. Zoega (2003): "Unions, WorkRelated Training, and Wages: Evidence for British Men," Industrial and Labor Relations Review, 57, 68-91.

Booth, A. L., and G. Zoega (1999): "Do quits cause under-training?," Oxford Economic Papers, 51, 374-386.

Brown, M., A. Falk, and E. Fehr (2004): "Relational Contracts and the Nature of Market," Econometrica, 72, 747-780.

Burdett, K., And E. Smith (2002): "The Low Skill Trap," European Economic Review, 46, 1439-1451.

Ciccone, A., and G. Peri (2002): "Identifying human capital externalities: theory with an application to US cities," IZA Discussion Paper No. 488, Bonn.

Dearden, L., H. Reed, and J. van Reenen (2000): "Who Gains When Workers Train? Training and Corporate Productivity in a Panel of British Industries," CEPR Discussion Paper No. 2486, London.

(2005): "The Impact of Training on Productivity and Wages: Evidence from British Panel Data," IFS Working Paper No. 16, London.

Estevao, M., and S. Tevlin (2003): "Do Firms Share their Success with Workers? The Response of Wages to Product Market Conditions," Economica, 70, 597-617.

FAlK, M., and F. Pfeiffer (1998): "Auswirkungen von Innovationen auf Lohn- und Produktivitätsangleichung zwischen ost- und westdeutschen Unternehmen," in Innovationen in Ostdeutschland - Potentiale und Probleme, ed. by M. Fritsch, F. Meyer-Krahmer, and F. Pleschak, pp. 145-167. Physica-Verlag, Heidelberg.

Fehr, E., And L. GÖtTe (2004): "Do workers work more when wages are high? Evidence from a randomized field experiment," IZA Discussion Paper No. 1002, Mannheim.

Garloff, A., And A. Kuckulenz (forthcoming): "Training, mobility and wages: specific versus general human capital," Jahrbücher für $\mathrm{Na}$ tionalökonomie und Statistik, forthcoming.

Griliches, Z., And J. MaIResse (1998): "Production Functions: The Search for Identification," in Econometrics and Economic Theory in the 20th Century, ed. by S. Stroem, pp. 169-203. Cambridge University Press, Cambridge.

Gürtzgen, N. (2005): "Rent-sharing: Does the Bargaining Regime Make a Difference? Theory and Empirical Evidence," ZEW Discussion Paper No. 05-15, Mannheim. 
Hempell, T. (2003): "Do Computers Call for Training? Firm-Level Evidence on Complementarities Between ICT and Human Capital Investments," ZEW Discussion Paper No. 03-20, Mannheim.

Hildreth, A. K., and A. J. Oswald (1997): "Rent-Sharing and Wages: Evidence from Company and Establishment Panels," Journal of Labor Economics, 15, 318-337.

IsACSson, G. (2005): "External effects of education on earnings: Swedish evidence using matched employee-establishment data," IFAU Working Paper 2005: 10, Uppsala.

JÜrges, H., AND K. SCHneIdER (2005): "Dynamische Lohneffekte berufliche Weiterbildung - Eine Längsschnittanalyse mit den Daten des SOEP," MEA Discussion Paper No. 92, Mannheim.

Kuckulenz, A. (2006): "Continuing Vocational Training in Germany - A Comparative Study using 3 German Data Sets," Unpublished Manuscript, ZEW Mannheim.

Kuckulenz, A., And M. Maier (2006): "Heterogeneous Returns to Training. An Analysis with German Data Using Local Instrumental Variables," Jahrbücher für Nationalökonomie und Statistik, forthcoming.

Kuckulenz, A., And T. Zwick (2003): "The Impact of Training on Earnings - Differences Between Participant Groups and Training Forms," ZEW Discussion Paper No. 03-57, Mannheim.

(2005): "Heterogene Einkommenseffekte betrieblicher Weiterbildung," Die Betriebswirtschaft, 65(3), 258-275.

Lazear, E. P. (2000): "Performance Pay and Productivity," American Economic Review, 90, 1346-1361.

López-Acevedo, G. (2003): "Wages and Productivity in Mexican Manufacturing," Policy research working paper 2964, World Bank, Washington.

Macleod, W. B., and J. M. Malcomson (1993): "Investments, Holdup, and the Form of Market Contracts," The American Economic Review, 83(4), 811-837.

Martins, P. S. (2005): "Firm-level social returns to education," IZA Discussion Paper No. 1382, Bonn.

McLaughlin, K. J. (1994): "Rent Sharing in an Equilibrium Model of Matching and Turnover," Journal of Labor Economics, 12, 499-523.

Piekkola, H., and A. Kauhanen (2003): "Rent Sharing as Firm Level Pay," International Journal of Manpower, 4, 426-451. 
Rennison, L. W., And J. Turcotte (2004): "Productivity and Wages: Measuring the Effect of Human Capital and Technology use from Linked Employer-Employee Data," Working paper, Finance Canada.

Zwick, T. (2002): "Continuous Training and Firm Productivity in Germany," ZEW Discussion Paper No. 02-50, Mannheim.

(2004): "Weiterbildungsintensität und betriebliche Produktivität," Zeitschrift für Betriebswirtschaft, 74(7), 651-668.

(2005): "Continuing Vocational Training Forms and Establishment Productivity in Germany," German Economic Review, 6(2), 155-184. 


\section{Appendix}

Table 6: Means and standard deviations

\begin{tabular}{lccc}
\hline Variable & Mean & Std. Dev. & Obs \\
\hline Wage (in logs) & 2.90 & 0.17 & 406 \\
Value added (in logs) & -3.19 & 0.47 & 382 \\
training & 0.03 & 0.02 & 406 \\
Capital (in logs) & -3.49 & 0.84 & 364 \\
Investments (in logs) & -5.17 & 0.85 & 385 \\
Labour (in logs) & -3.51 & 1.05 & 385 \\
Job change & 0.10 & 0.03 & 406 \\
High skilled & 0.24 & 0.14 & 406 \\
Women & 0.44 & 0.21 & 406 \\
East & 0.03 & 0.01 & 406 \\
Tenure 0-4 & 0.35 & 0.09 & 406 \\
Tenure 5-9 & 0.22 & 0.04 & 406 \\
Tenure 10-14 & 0.13 & 0.03 & 406 \\
Tenure 15-19 & 0.08 & 0.02 & 406 \\
Tenure 20-29 & 0.13 & 0.05 & 406 \\
Tenure 30-39 & 0.05 & 0.02 & 406 \\
Tenure 40-51 & 0.01 & 0.01 & 406 \\
Age 17-20 & 0.01 & 0.01 & 406 \\
Age 21-25 & 0.07 & 0.02 & 406 \\
Age 26-30 & 0.12 & 0.02 & 406 \\
Age 31-35 & 0.15 & 0.02 & 406 \\
Age 36-40 & 0.16 & 0.02 & 406 \\
Age 41-50 & 0.27 & 0.03 & 406 \\
Age 51-65 & 0.22 & 0.04 & 406 \\
\hline
\end{tabular}

Table 7: Training intensity by economic sector

\begin{tabular}{lc}
\hline \multicolumn{1}{c}{ Sector } & $\begin{array}{c}\text { Training } \\
\text { (in percent) }\end{array}$ \\
\hline Education and teaching & 0.07 \\
Activities connected with banking and insurance industry & 0.06 \\
Health care, veterinary medicine and welfare & 0.06 \\
Insurance industry & 0.06 \\
Banking sector & 0.06 \\
Lobbies, churchly and other religious unions & 0.05 \\
Data handling and databases & 0.05 \\
Manufacture of office machines and data handling equipment & 0.05 \\
Civil service, defence, social insurance & 0.05 \\
Research and development & 0.04
\end{tabular}

to be continued... 
...table 7 continued

Sector Training

(in percent)

Aviation

0.04

Energy supply

0.04

Coking plant and petroleum processing 0.03

Chemical industry $\quad 0.03$

Water supply 0.03

Broadcast, television and communications engineering 0.03

Services mainly for establishments 0.03

Manufacture of electricity production and allocation equip- $\quad 0.03$

ment

Premises and housing $\quad 0.03$

Telecommunications $\quad 0.03$

Culture, sport and entertainment 0.03

Manufacture of automobiles and automobile particles 0.03

Other vehicle construction $\quad 0.03$

Medical technology, measurement, control technology, optics $\quad 0.02$

$\begin{array}{ll}\text { Other services } & 0.02\end{array}$

Extraterritorial organisations and statutory corporations $\quad 0.02$

$\begin{array}{ll}\text { Engineering } & 0.02\end{array}$

Extraction of crude oil and natural gasoline and with it con- $\quad 0.02$

nected services

Forestry 0.02

Automobile trade, maintenance and mending of automobiles, $\quad 0.02$

petrol station

Tobacco processing $\quad 0.02$

Land transport, transport via pipelines $\quad 0.02$

Metal production and machining $\quad 0.02$

Commerce intermediation and whole sale 0.02

Publisher and print trade, duplication of played 0.02

Sound storage medium, picture carrier and record carrier

Waste, sewage and other disposal $\quad 0.02$

Coal mining, extraction of turf 0.02

Auxiliary activities and additional businesses for traffic, traf- $\quad 0.02$

fic intermediation

Manufacture of vulcanised rubber and plastic goods 0.02

Retail, mending $\quad 0.02$

Manufacture of metal manufactures $\quad 0.02$

Glass trade, ceramics, processing of stones and earthen 0.02

$\begin{array}{ll}\text { Paper trade } & 0.01\end{array}$

Construction $\quad 0.01$

Wood trade 0.01

Textile processing $\quad 0.01$

to be continued... 
...table 7 continued

\section{Sector}

Training

(in percent)

Extraction of stones and earthen, other mining

0.01

Navy

0.01

Agriculture and hunting

0.01

Clothing trade

0.01

Manufacture of furniture, jewellery, musical instruments,

0.01

pieces of sports equipment and other manufactures

Renting of chattels without operating staff

0.01

Hotel and restaurant industry

0.01

Nutrition trade

0.01

Recycling

0.01

Private households

0.01

Leather trade

0.01

Fishery and fish farming

0.00 